Article

\title{
Governing GMOs: The (Counter) Movement for Mandatory and Voluntary Non-GMO Labels
}

\author{
Carmen Bain * and Tamera Dandachi \\ Department of Sociology, Iowa State University, 316 East Hall, Ames, IA 50011, USA; \\ E-Mail: tameradandachi@gmail.com \\ * Author to whom correspondence should be addressed; E-Mail: cbain@iastate.edu; \\ Tel.: +1-515-294-9895.
}

External Editors: Douglas H. Constance and Maki Hatanaka

Received: 10 September 2014; in revised form: 20 November 2014 / Accepted: 2 December 2014 / Published: 18 December 2014

\begin{abstract}
Since 2012 the anti-GMO (genetically modified organism) movement has gained significant grassroots momentum in its efforts to require mandatory GMO food labels through state-level ballot and legislative efforts. Major food and agriculture corporations are opposed to mandatory GMO labels and have successfully defeated most of these initiatives. Nevertheless, these battles have garnered significant media attention and re-energized the debate over GMO crops and foods. In this paper, we argue that one of the most significant outcomes of this fight is efforts by food retailers and value-based food companies to implement voluntary non-GMO labels and brands. We draw on the governance and political consumerism literature to explore (counter) movement efforts for mandatory labels and how these efforts are being institutionalized through private voluntary governance institutions. Our assessment is based on in-depth, semi-structured interviews with key informants from consumer and environmental organizations, agriculture and biotech companies, and government regulatory agencies, as well as a content analysis of food industry websites. A growing number of food retailers recognize the reputational and economic value that new niche markets for non-GMO foods can offer, while the anti-GMO movement views these efforts as a step in the direction of mandatory GMO labels. We conclude that voluntary labels may act to settle the labeling debate by mollifying agri-food industry concerns about mandatory labeling and meeting the desire of political consumers for greater choice and transparency but without addressing the broader social and environmental sustainability concerns that drives the anti-GMO movement in the first place.
\end{abstract}


Keywords: GMO labels; governance; social movements; food retailers; political consumerism; transparency

\section{Introduction}

Since 2012 the anti-GMO (genetically modified organism) movement in the US has gained significant momentum in their efforts to label genetically modified [1] foods. The movement has succeeded in getting ballot initiatives or legislation to mandate GMO food labels introduced in numerous states across the country. According to the National Conference of State Legislatures, 28 states introduced labeling bills in 2014 [2]. Four states [3] have held ballot measure elections including California in 2012, Washington in 2013, and Colorado and Oregon in 2014. Connecticut and Maine each passed legislation in 2013 mandating GMO labels, while Vermont passed similar legislation in 2014. Over \$25 million was spent trying to win the four ballot initiatives. To date, voters have narrowly rejected each ballot proposal for mandatory labels, and due to contingencies in the legislation only Vermont's law, if it withstands a court challenge from the food industry, is likely to go into effect. Despite defeats at the ballot box, the anti-GMO movement has succeeded in reigniting a national debate and raising public awareness about GMOs nearly two decades after GMO crops were first commercially introduced [4-6].

Opposition to GMO crops and foods is driven by a broad range of socio-economic, legal, and environmental concerns, from food safety risks, the perceived lack of federal food safety and environmental oversight, corporate control of seeds and patents, to the agrichemical treadmill and the development of "superweeds". Previous social movement efforts to ban GMO crops, and ongoing attempts to introduce federal legislation that would require GMO labels, have remained largely unsuccessful [7]. The US Food and Drug Administration (FDA), the government agency responsible for the food safety of GMO crops, has determined that GMO foods are substantially similar (i.e., there is no material difference) to non-GMO foods and therefore labeling is not required [8]. In contrast, proponents of GMO labeling argue that consumers have "a right to know" what they are buying, that consumers should be able "to choose" whether they purchase foods that contain GMO ingredients, and that GMO labeling would deliver greater "transparency" in the food system [9-12]. To support these claims, labeling proponents point to an array of surveys that show that American consumers desire some sort of GMO labeling $[8,13]$.

The agri-food industry is overwhelmingly opposed to mandatory labeling; arguing that GMO foods are safe and mandatory labels would have a costly and detrimental effect on consumers, food producers, and food manufacturers. Food companies, such as Nestle, together with biotech companies, such as Monsanto, spent over a $\$ 100$ million to defeat the four state ballot initiatives. In addition, Vermont's mandatory labeling law was immediately challenged in federal court by four food industry associations, led by the Grocery Manufacturers Association (GMA). The stakes in this battle are high since mandatory GMO labeling would have an enormous impact on the US agri-food system where 90 percent of all corn, soybeans and sugar beets are genetically engineered and 80 percent of all processed food includes at least one ingredient derived from a genetically engineered crop [10,14-16]. 
While much of the public attention has focused on the battle over mandatory labeling, we argue that of potentially greater long-term significance are current voluntary private governance initiatives. While most corporate actors feel threatened by mandatory GMO labels and the economic and logistical burden it would impose on them, some corporate actors, especially food retailers and values-based food companies, are recognizing the value of voluntary non-GMO labels and brands. These actors are moving to introduce non-GMO labels and brands or to ban GMO foods from their stores. In 2014, for example, Whole Foods announced that all its products will require GMO labeling by 2018, Target announced their own product line "Simply Balanced" will be non-GMO by the end of the year, and Boulder Brands introduced their non-GMO Smart Balance margarine.

In this paper, we draw on the governance and political consumerism literature to examine how social movements are mobilizing around labeling as well as how political consumerism is being institutionalized through private standards, product labels, and certification. Since political consumerism is both "a form of political participation and [a] form of governance" [17] (p. 9), we examine contemporary efforts by the non-GMO movement to mobilize political consumers as well as efforts by the food industry to institutionalize political consumerism through product labels for GMO foods. Following Roff [18], we argue that intransience at the federal level has encouraged consumer, social, and environmental activist groups who are opposed to GMOs to shift away from targeting the nation-state and seeing the state "as an arena of political bargaining" to a focus on activism where individuals are empowered to accomplish movement goals through their role and identity as consumers [18]. Here, citizens are encouraged to express their political concerns through their consumption practices, for example, by consciously choosing to buy products - "buycotting" - that they view as socially or environmentally progressive - or boycotting products that are not [17]. As we have seen in other private governance issues [19], many food retailers recognize the brand, market, and reputational value that meeting activist and consumer demands for enhanced choice and transparency related to GMO foods can present.

In the next section, we provide an overview of the methods used to conduct this research. Following that, we describe the governance and political consumerism literature that informs our analysis. We then draw on data from the interviews and our content analysis of websites to understand what and who is driving private governance of GMOs and why. We conclude by considering the implications of private governance efforts and political consumerism to address the social, environmental, and sustainability concerns of the anti-GMO movement. We find that in an effort to mobilize consumer and retailer support for GMO labeling, the core social and sustainability concerns of the non-GMO movement are minimized in favor of a discourse by both activists and retailers emphasizing neoliberal, individualist arguments that labels enhance the ability of individuals to freely act and make good choices in the marketplace. We conclude that voluntary labels may have the unintended consequence for the anti-GMO social movement of settling the labeling debate by mollifying agri-food industry concerns about mandatory labeling and meeting the desire of political consumers for greater choice and transparency. But, that this settlement is likely to occur without addressing the broader social and environmental sustainability concerns that drives the anti-GMO movement in the first place. 


\section{Methods}

In-depth, semi-structured interviews were conducted with 24 key informants who were sampled purposively because of their expertise on GMOs in the agri-food sector. These interviews are part of a larger project investigating societal acceptance issues related to GMOs in the US Informants represented consumer and environmental advocacy organizations, agriculture and biotech companies, and government regulatory agencies. The interviews were conducted between July 2013 and August 2014. Most of the interviews took place in person while some were conducted via phone, and each interview lasted approximately one hour. A common interview protocol was used for each interview, although it was tailored to the expertise of each participant. Interviews were structured to gather data on informant's understandings of the key debates, political actions, and regulatory processes taking place regarding GMOs as well as their drivers and broader policy and societal implications. All interviews were recorded, transcribed verbatim, and then analyzed using NVivo for key themes intended to understand what and who is driving GMO labeling efforts, the benefits and burdens of labeling for different stakeholders, and how the debate is being framed.

Data was also collected through a content analysis of nine major food retailer and food processor, as well as non-GMO certifier websites. We selected companies that have developed private standards, labels or brands for non-GMO products, and we analyzed this data to understand private governance efforts related to GMOs as well as their justification for providing non-GMO options for consumers.

\section{Private Governance and Political Consumerism of Non-GMO Labeling}

Over the past two decades, a confluence of forces has created new opportunities for non-state actors, including food retailers and social movements, to develop institutions to govern the agri-food system. These governance institutions include standards, labels, and certification systems [20]. In particular, market consolidation has created retail oligopolies with significant political, economic and discursive power [21-23]. Paradoxically, as food retailers have assumed greater market dominance they have become more susceptible to activist and consumer concerns about the food system. Social movements have emerged as key actors in framing food and agricultural issues as a social problem and mobilizing political consumers to address their concerns through the market [20]. These concerns include food safety and health risks related to, for example, pathogens such as e-coli, pesticides residues and genetic engineering, as well as broader concerns about the effects of food production on the environment, family farms, farm workers, and animals [24-26].

Previously, food movements sought to transform agricultural production practices by targeting government regulation or by creating alternatives to industrial agriculture. Today, however, activism itself has become "neoliberalized" with many activist organizations focusing on reforming the agricultural market through individual consumption practices $[18,27,28]$. In other words, consumption is now viewed as a political practice, a way to change the world, and the most promising means of providing "alternative agri-futures" $[17,18,28]$. Social movements attempt to use consumer power to transform the practices of major food retailers. For example, social activists use confrontational strategies, including media protests to highlight the negative social and environmental practices of highly visible corporations, such as a McDonalds, Walmart, or Safeway [29]. Many of these corporations 
discover that they are not immune to embarrassing "naming and shaming" strategies and that their bottom line can be directly affected, especially when their valuable brand names and corporate reputations are linked to objectionable environmental and social practices [17,20,29,30].

At the same time, political consumerism is driving new market opportunities for retailers. Within oligarchic markets, firms are eager to find alternatives to price based competition and consumer and activist demand is providing the ability for retailers to differentiate their food products based on non-price attributes, such as health, quality, or variety [31-34]. Agricultural and food products represent a host of quality attributes, known as credence goods, which are related to how the product was produced, its make-up, or wider implications related to its production that may not be visible or discernible to the consumer. Examples include organic, natural, genetically engineered, pesticide residues or animal welfare $[28,33,35]$. While the market for these alternative niche products is small, it is valuable for retailers who recognize that an important segment of consumers is willing to spend more on products that make them feel like they are acting in a socially and environmentally responsible fashion [36-38].

The development of governance institutions, such as green or sustainability labels, is necessary to the creation of niche markets. Examples of such labels include rBGH-free milk or Non-GMO Project Verified, which are developed by retailers or social movements. While such market institutions can incur costs and risks, their ability to convey credence attributes to consumers make them valuable to retailers in a number of ways. These labels improve the ability of retailers, as well as food processors and producers, to enhance their reputation as socially and environmentally responsibility. Labels can also act to enhance the perception of retailers and producers as trustworthy among consumers $[19,23]$. Failure by a food supplier to provide and assure consumers about food safety and quality increases the risk of tarnishing one's reputation and financial standing [33]. Private standards can protect a retailer's reputation by improving the social and environmental performance of its suppliers throughout the value chain, thereby minimizing the risk of scandal [21,22]. Private standards can also function as a means for quelling calls for tighter government oversight and mandatory regulation [39]. Thus, companies with direct links to consumers have increasingly demonstrated a willingness to meet the demands of social activists and political consumers $[19,23]$.

For social movements, the development of private governance institutions, such as non-GMO labels, are viewed as necessary to enhancing transparency and consumer choice related to political consumption [40,41]. Mol argues that transparency is increasingly valued by those concerned with environmental and sustainability issues since it is assumed that more transparency will "empower the weak and hold the more powerful accountable through reducing information asymmetries, enabling more equal participation around political controversies and enhancing accountability" [41]. The assumption is that transparency empowers consumers to make better choices, thereby leading to more sustainable agri-food systems.

We now turn to discuss social (counter) movement efforts for labeling in the US Food labeling is always political or as Beck has argued "subpolitical" in that it often takes place outside the representative institutions of the nation-state within a context of social movements mobilizing for and against labeling [17]. In the following sections, we briefly describe federal regulations of GMO crops, foods, and labeling. We then elaborate on the subpolitical mobilization efforts of the anti-GMO movement to engage in political consumerism and efforts to label GMO foods and how the food industry has responded to these efforts. 


\section{Federal Regulation of GMO Crops and Foods}

In the 1980s, US government policy determined that biotechnology was necessary for the success of US agriculture [42]. The framework adopted for evaluating GMOs is based on risk assessment, where risk is defined in purely biophysical terms and the assessment assumes that science is not influenced by outside factors $[42,43]$. Here, risk assessment evaluates the probability of harm of the new technology to human health or the environment but not the broader economic or social risks associated with it. The risk-based framework adopted by the US for evaluating GMOs differs substantially from the precautionary approach adopted by the European Union $[42,43]$.

The 1992 FDA policy on regulating GMOs states that genetically engineered (GE) plants should produce products that are "substantially similar" to unmodified plants [42]. The FDA assured consumers that GE foods were not a threat to human health or environmental safety, a position it continues to hold [8]. In its 1992 statement of policy, Foods Derived from Plant Varieties, the FDA reiterated the regulatory adjustments put forth in the 1986 Coordinated Framework for Regulation of Biotechnology, stating that the FDA will regulate GE products no differently than those produced through conventional techniques since foods developed using genetic engineering pose no additional risk [8]. The FDA does not require that GE foods be labeled because from its perspective genetic engineering does not materially change food $[44,45]$.

In 1993, the FDA approved the recombinant bovine growth hormone (rBGH, also known as rBST) (which increases milk production in dairy cows), which was followed by the first GE tomato (which proved to be commercially unsuccessful). By 1996, the FDA had also approved several other GE crops such as cotton, soybeans and squash [8]. The FDA continued to approve numerous GMO foods from 1994 to 2007. In 2001, the FDA implemented a change in policy requiring that GE food developers submit data regarding plant-derived GE food at least 120 days prior to market release [8]. By 2003, the FDA had dropped the requirement that developers submit data, as well as the voluntary consultation, and reverted to its 1992 policy which stated that GE foods are safe and do not pose any concerns.

The FDA allows process-based non-GMO labeling "as long as it is not false or misleading" [10] (p. 5). For example, milk labeled rBST or rBGH free is required to carry a government disclaimer noting their position that "no significant difference has been shown between milk derived from rBST-supplemented and non-rBST-supplemented cows." A major milestone for GMO labeling advocates took place in 2013 when the USDA (US Department of Agriculture) approved a label for meat and liquid egg products that claim the products came from animals that were raised on non-GMO diets [46]. The USDA is responsible for approving all meat labels as truthful and not misleading to consumers. This is the first time that the USDA has approved of a non-GMO label claim. The Non-GMO Project, an independent organization established in 2007 that sets standards, certification, and a label for non-GMO products, is the group who certifies the products [47].

Federal legislative efforts for labeling have remained unsuccessful. Former Congressman Dennis Kucinich introduced legislation entitled, "Genetically Engineered Food Right to Know Act" six times from 1999 to 2011, which would require GMO labeling. Californian Senator Barbara Boxer first introduced a bill in 2000 that would require the FDA to label foods made with GMOs [48]. Together with Congressman DeFazio, Senator Boxer reintroduced the legislation, "Genetically Engineered Food Right-to-Know Act," again in April 2013, but it has not received congressional support and is unlikely to in the near future. 


\section{The GMO (Counter) Movement and Labeling}

In the US, anti-GMO opposition dates back to the 1970s when activists opposed to genetically engineered crops and foods began to organize. Schurman and Munro (2010 argue that by the late 1990s, this opposition had developed into an anti-GMO social movement [7]. The primary goal of the movement was to halt the development of GMO crops or failing that prevent their commercialization. However, their efforts met with limited success. Activist organizations involved were able to delay for several years Monsanto's efforts to gain approval for rBST as well as keep Roundup Ready wheat off the market [7]. The movement gained momentum when tests of several major brands of taco shells in 2000 revealed that they contained a Bt protein approved for animal feed but not approved for human consumption [8]. The anti-GMO movement used this incident to call attention to the problem of GMOs in the food system and the inadequacy of the regulatory process; however, these efforts did not result in any changes to federal regulatory oversight [44]. Efforts to have GMO food labeled were also unsuccessful. In 2002, the first state initiative for GMO food labeling was placed on the ballot in Oregon, which was decisively defeated with over 70 percent of voters opposed [49].

The success of the anti-GMO movement was also hindered by a lack of public support. The public knew very little about biotechnology, including GMOs, in the 1990s. The majority of the discourse surrounding GMO foods was positive and the support rate for biotechnology was steady around 70 percent for most of the 1990s [50]. The public appeared to remain in support of GMO foods through the 1990s and believed that there would be tangible gains associated with the use of biotechnology [8]. At the same time, early studies also showed that American consumers desired some sort of regulation or labeling of GMOs [8,9,11,12].

By the end of 2008, it appeared that the anti-GMO movement in the US was finished as efforts to outright ban or slow the commercialization of GMO crops or label GMO foods were crushed and GMO crops had become pervasive throughout the US food system [7]. The anti-GMO movement was also forced to play defensive as the world food crisis that began in 2007 added legitimacy to arguments that GMO crops were necessary to address global hunger and food insecurity [7].

However, speculation that the anti-GMO movement was finished proved to be premature. By 2012, the GMO debate was once again grabbing national attention and grassroots momentum was growing as the anti-GMO movement had regained its footing by shifting its focus away from banning GMO crops instead intensifying its demands for GMO labeling. While the ultimate goal of mandatory labeling advocates is a national solution [51], labeling initiatives are focused on two grassroots sub-national mobilization strategies. The first is to target individual states to mandate labeling through ballot initiatives or legislative bills and the second strategy is to target individual food companies to label their own products, introduce non-GMO brands, or ban GMO products entirely.

\section{Mobilizing for-and Against—Mandatory Labels}

Social movement efforts to legislate mandatory GMO labels at the state-level are the most extensive ever seen (see Figure 1). The first major battleground was California's Proposition 37, a ballot initiative calling for mandatory GMO labeling held in November 2012, which was defeated 53-47. This was followed in 2013, with Washington State's ballot initiative 522, which was closely defeated 51-49. 
In 2014, grassroots efforts focused on Oregon's Measure 92 and Colorado's Proposition 105. Colorado's ballot initiative was defeated 66-34. In Oregon, the hardest fought state where the ballot had the greatest likelihood of passing, the measure was defeated by a mere 809 votes (out of approximately 1.5 million cast), triggering an automatic recount. However, the recount did not change the result significantly and Measure 92 was lost. Despite losing all ballot initiatives, proponents of labeling have regarded these efforts as successful in the sense that they have catapulted the issue of GMO foods and labeling into the national spotlight as a topic of debate [52]. A participant from a consumer advocacy organization expressed a theme common among pro-labeling participants: "Some people don't view defeat [at the ballot box] as a loss for the issue and rather see it as something that has put the issue on the national stage" [53]. Certainly, the debate is far from over. In 2014 alone, 28 states have introduced labeling bills [2]. In 2013, both Connecticut and Maine passed a law requiring GMO labeling. However, these laws are contingent on four other surrounding states, with a combined population of over 20 million, enacting similar legislation [54]. In April 2014, Vermont's state legislation passed a GMO labeling law (Act 120), which has no contingencies and is set to take effect 1 July 2016.

Figure 1. 2014 GMO Legislation Tracking Map.

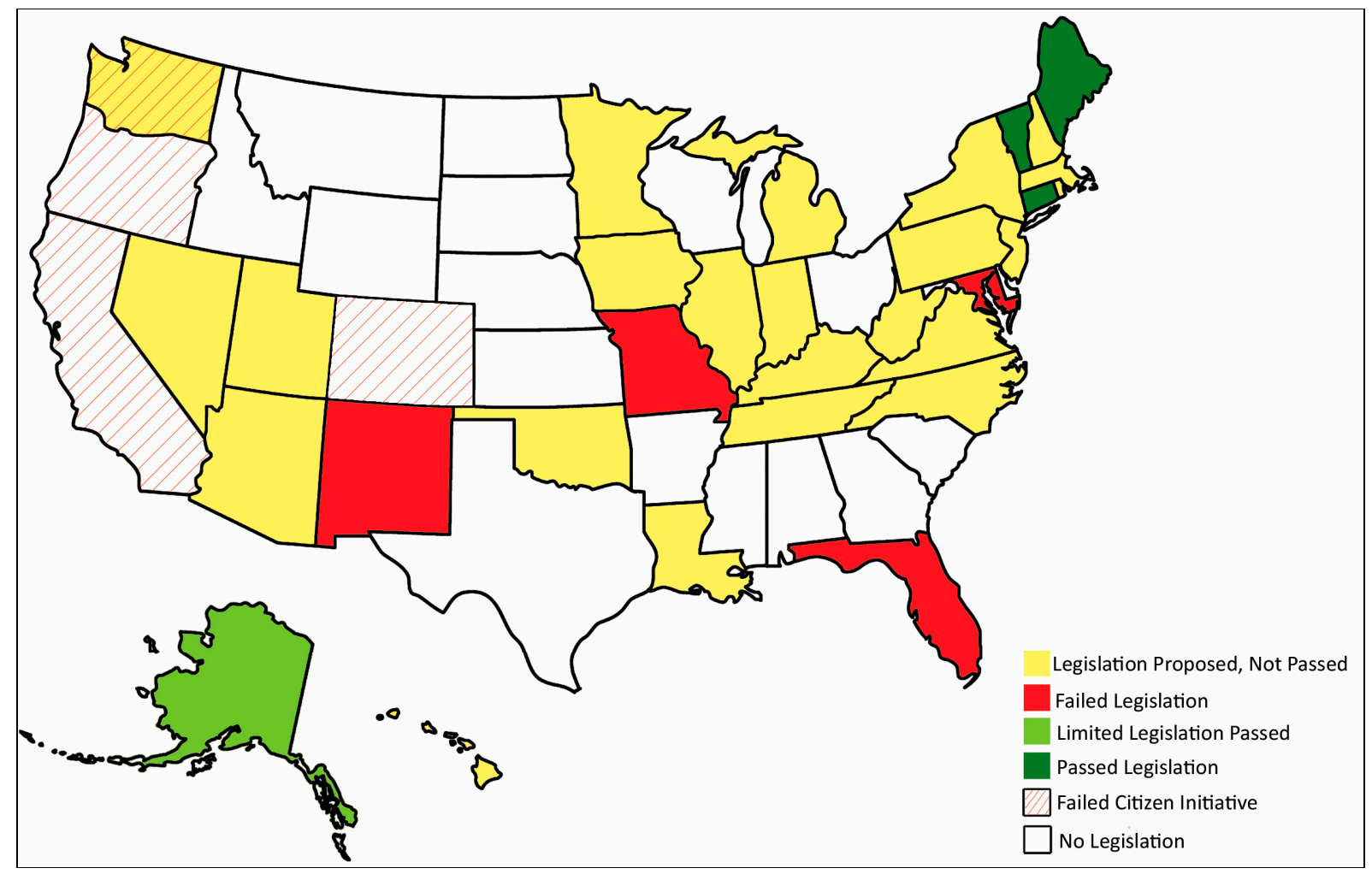

Social movement opposition to GMOs embodies a wide range of socio-economic, environmental and sustainability concerns that include - but also go beyond - scientific concerns over food safety. As one participant put it, "GMOs are ... a place for people to focus other broader moral concerns about sustainable agriculture or the food that they're eating" [55]. These range from the Center for Science in the Public Interest's concern that FDA oversight of GMO foods is "not as rigorous or as independent as it should be" and that the FDA should require "a mandatory pre-market approval process" rather than their current "voluntary notification process" [14] (p. 5), [56] to much more critical concerns raised by 
groups such as the Center for Food Safety, Organic Consumers Association, Food \& Water Watch, and the Environmental Working Group. Here, concern exists in relation to the role that GMO technology plays in shaping how the agri-food system is organized, by whom, and for whose benefit. This includes, for example, corporate control of GMO seeds and patents, the potentially negative effects of genetic engineering on wildlife (such as the monarch butterfly) and ecosystems, and GMO contamination of organic crops. The recent development of "superweeds"- and EPA approval of more powerful herbicides, such as 2,4-D, to kill glyphosate resistant weeds-has only intensified concerns among opponents of GMOs about the role of GMOs in perpetuating the herbicide treadmill.

However, in its efforts to mobilize support for non-GMO labels among the general public, the anti-GMO movement has largely focused on neoliberal arguments that labels would enhance the ability of individuals to freely act in the marketplace. The demand for labels is advanced through three core frames: that individual consumers should have "a right to know" what is in their food, that consumers should be able "to choose" whether to purchase foods made from GMO ingredients, and that GMO labeling would deliver greater "transparency" in the food system [10-12]. For example, the slogan for Oregon Measure 92 is "Oregon right to know" and the webpage states: "The Oregon Right to Know initiative is about transparency and empowering shoppers. This is not a ban on genetically modified food and this is not a debate on the science. It's about consumers getting the information we need to make our own decisions about the food we feed our families" [57]. Anti-GMO participants we spoke with believe that such framing is effective and that grassroots momentum around GMO labeling is largely motivated by the desire of consumers for more choice and transparency in the food system. As one participant put it: "It's really about people wanting to have a say about what they eat ... There's a larger fight about transparency in the food system that is taking place and GMOs are just part of that" [58].

Overwhelmingly, the food industry opposes mandatory GMO labeling whether at the state level, which would create "a patchwork of different labels" or a uniform, mandatory law at the federal level. Led by the GMA, food companies, such as Nestle, Kraft Foods and Coca-Cola, have joined with major seed, chemical and biotech companies, such as Monsanto, DuPont Pioneer, Bayer CropScience, Dow AgroSciences and BASF Plant Science, to defeat state ballot initiatives. Companies opposed to labeling spent over $\$ 100$ million to defeat the four ballot initiatives that have taken place in California, Colorado, Oregon, and Washington, outspending proponents four-to-one (See Table 1). The GMA has also made it clear that it would initiate court proceedings against any state that passes a mandatory labeling law. When Vermont did just this in April 2014 with Act 120, its constitutionality was immediately challenged in federal court in June 2014 by the GMA, the Snack Food Association, the International Dairy Foods Association, and the National Association of Manufacturers. In April 2014, US Representative Mike Pompeo (R-KS) introduced legislation, The Safe and Accurate Food Labeling Act (HR 4432). The proposed legislation, which has broad agri-food industry support, would prevent individual states from passing legislation requiring the labeling of GMO food and beverage products.

In its efforts to defeat mandatory GMO labeling efforts, the food industry has focused on countering the neoliberal arguments advanced by GMO labeling supporters by focusing on issues of food safety, cost, and choice, which they believe to be effective arguments with consumers. One participant from the biotech industry argued that the defeat of California I-522 "highlighted the fact that if you educate people about the debate ... and that probably the net result is that their food cost is going to increase ... they vote "no"" [59]. Opponents of mandatory labeling argue that there is no scientific justification to oppose 
GMO foods with hundreds of independent studies demonstrating that GMO foods are safe and premarket assessments for food safety to evaluate any possible risks [10]. In opposing Vermont's mandatory GMO labeling law, the GMA argued that the Act "is a costly and misguided measure that will ... do nothing to advance the health and safety of consumers" [60].

Table 1. Comparison of campaign expenditures on statewide non-GMO ballot initiatives, 2012-2014.

\begin{tabular}{lrrr}
\hline Ballot Initiative & Proponents & Opponents & Total \\
\hline California Proposition 37 (2012) & $\$ 9,157,552$ & $\$ 45,970,905$ & $\mathbf{\$ 5 5 , 1 2 8 , 4 5 7}$ \\
Washington Initiative 522(2013) & $\$ 8,085,413$ & $\$ 22,010,091$ & $\mathbf{\$ 3 0 , 0 9 5 , 5 0 4}$ \\
Oregon Measure 92 (2014) & $\$ 8,022,647$ & $\$ 20,486,102$ & $\mathbf{\$ 2 8 , 5 0 8 7 4 9}$ \\
Colorado Proposition 105(2014) & $\$ 625,968$ & $\$ 12,665,225$ & $\mathbf{\$ 1 3 , 2 9 1 , 1 9 3}$ \\
Total & $\mathbf{\$ 2 5 , 8 9 1 , 5 8 0}$ & $\mathbf{\$ 1 0 1 , 1 3 2 , 3 2 3}$ & $\mathbf{\$ 1 2 7 , 0 2 3 , 9 0 3}$ \\
\hline
\end{tabular}

Opponents also reject the argument that mandatory labeling creates choice. One government biotechnology official argued that there is inevitably a tradeoff between transparency and choice. In Europe, he argued, where mandatory labeling exists there is greater transparency but since companies have chosen not to make GMO products available as a consequence "consumers have no choice and farmers have no choice" [61]. In contrast, in the US, he said, "If you don't want biotech products there are literally tens of thousands of choices in the grocery store. There are organic products and products labeled as non-GMO" so here "we're delivering choice to consumers" [61].

Other proponents of GMOs in our study similarly argued that consumer choice could be satisfied through the use of voluntary, non-GMO labels, such as the Non-GMO Project or the USDA Organic label, which would not impose unnecessary costs on the entire industry or all consumers. A policy of voluntary labeling would allow those who wish to purchase only non-GMO foods to pay a premium for products that do not contain GMOs. Mandatory labeling of GMOs would present a higher cost for all consumers if all costs were to be internalized by consumers, including those who are not interested in avoiding GMOs [10,62]. However, the exact cost is disputed. On the one hand, the GMA predicted price increases of around $\$ 500$ per household [63] if mandatory labeling were to be implemented. On the other hand, the Consumers Union argues that price increases due to mandatory labeling would range from $\$ .32$ to $\$ 15.01$ per person per year [64]. It is not certain how much consumers would be willing to pay for GMO labeling [60]. Eenennaam et al. [10] cite a survey from 2001 that shows that a third of those surveyed (33 percent) would be willing to pay more than $\$ 50$ per year for GMO labeling.

\section{Mobilizing for Voluntary Labels}

While mobilizing for mandatory labels, anti-GMO activists are also using a variety of tactics, such as boycotts and buycotts, to compel individual companies to voluntarily label their products non-GMO or to not carry GMO products at all. The idea is that companies, especially those with direct links to consumers or high-profile, valuable brand names, will be concerned that any negative publicity could lead some consumers to reject their brands or shop elsewhere. At the same time, some food companies are attentive to the fact that activist efforts for mandatory labeling, which have greatly increased consumer awareness regarding GMOs, are providing new market opportunities that they wish to take advantage of. As the CEO of Smart Balance said in response to introducing their non-GMO label, "I've 
been in the food industry for 35 years [and] I have never seen a consumer issue come on this fast" [65]. According to the market-research firm Nielsen, " "non-GMO' is one of the fastest-growing labels trends" with sales growing 28 percent in 2013 to about $\$ 3$ billion [16].

Social movement campaigns for non-GMO labels are coinciding with a key trend in food retailing: the development of private labels to compete with national brands. Private labels are extremely important for food retailers because they carry higher profit margins than branded products from manufacturers and they provide a means for retailers to differentiate themselves from their competition $[66,67]$. The market share of private retailer labels is expected to continue to grow "potentially doubling in size by 2017" [68]. Until recently, private label brands were synonymous with cheap, lower quality, and did not have the "trust of their name-brand competitors" [69]. But this has changed. Today, private label brands are not only able to compete directly with traditional, national brands in terms of quality and trustworthiness but are also being used by retailers to innovate and inspire product categories [69]. This trend was pioneered a decade ago by Whole Foods with its 365 Everyday Value brand, which has established itself as "The brand that most folks want to emulate," according to one supermarket consultant [70]. In 2012, private label sales for Whole Foods were estimated at \$1.7 billion [70].

In 2001, Trader Joe's was the first retailer to go non-GMO with its private label products (with the exception of its animal products), which account for about 80 percent of its stock. In 2009, Whole Foods became the largest retailer of non-GMO products when its 365 Everyday Value brand went non-GMO, carrying the Non-GMO Project Verified label. Some of the largest food retailers in the US have recently followed suit. In 2013, Target created its private label, Simply Balanced. Of the 250 products available, 40 percent are certified organic and three-quarters are non-GMO. Its goal is to eliminate all GMO-based ingredients from the label by the end of 2014 [66].

To enhance transparency, trust, and credibility, it is increasingly the norm for companies to use independent third party certifiers to verify claims related to credence goods, such as non-GMO [20]. While several major companies, including Target and Whole Foods, use the Non-GMO Project Verified to certify and label their non-GMO products, it is interesting to note that most company claims are not independently verified (see Table 2). For example, while Trader Joe's state that they do not us GMO ingredients they do not label their products as "non-GMO", which they argue is because there are no set guidelines from the FDA [71].

The growth in non-GMO products is also being driven by consumer interest in organic and natural products [72]. Sales of organic and natural increased 13.5 percent from 2011-2012 to $\$ 81.3$ billion and this growth is expected to continue [70]. Supermarkets are taking advantage of these trends by establishing their own private organic labels. Retail giants Kroger launched Simple Truth Organic in 2012 and Aldi SimplyNature in 2014, both of which are certified USDA organic. The USDA's organic label prohibits GMOs in all its products, including fresh produce, meat and processed foods. In the absence of mandatory GMO labeling, some industry experts expect sales in certified organic products to expand further as consumers seeking assurances that their food products do not contain GMO ingredients purchase certified organic [73]. 
Table 2. Non-GMO governance strategies of major food retailers and manufacturers.

\begin{tabular}{llll}
\hline Governance Strategy & Year & Retailer/Manufacturer & Third Party Certification \\
\hline \multirow{2}{*}{ GMO Free } & 2014 & Ben and Jerry's & None \\
\cline { 2 - 5 } & 2014 & Chipotle & None \\
\hline \multirow{2}{*}{$\begin{array}{l}\text { Non-GMO } \\
\text { Retailer Brand }\end{array}$} & 2014 & Target "Simply Balanced" & Non-GMO Project Verified \\
\cline { 2 - 4 } & 2001 & Trader Joe's store brand & None \\
\hline \multirow{2}{*}{$\begin{array}{l}\text { Non-GMO Label } \\
\text { Manufacturer Options }\end{array}$} & 2009 & Whole Foods Market "365 Everyday Value" & Non-GMO Project Verified \\
\cline { 2 - 4 } & 2014 & Boulder Brands "Smart Balance Buttery Spread" & None \\
\cline { 2 - 4 } & 2013 & General Mills "Cheerios" & None \\
\hline
\end{tabular}

Food retailers are increasingly sensitive that to build trust in, and reduce risk to, their valuable brand names and private labels, they must establish a reputation as socially and environmentally responsible. Many major retailers have responded to "name and shame" tactics that could negatively affect their reputation and thus bottom line by eliminating GMO products that are especially controversial from their store brands or their stores. Activist pressure and consumer demand for "hormone-free" milk has lead to a number of major food processors and retailers banning the use of rBST in their private labels [74], such as Walmart's Great value milk in 2008, or products, such as General Mills's Yoplait in 2009. Activists have used petitions, social media, and consumer boycotts to dissuade food retailers from carrying AquaBounty Technology's GMO salmon should it be approved for commercial release by the FDA. This salmon would be the first GMO animal produced for direct human consumption. Over 60 supermarkets, including food-retailing giants Aldi, H-E-B, Safeway, Kroger, Target, Trader Joe's, and Whole Foods have agreed not to carry the GMO salmon [75]. The preemptive refusal by retailers to carry GMO salmon may signal its commercial doom. In 1994, the fast-food industry, principally McDonalds, faced activist pressure to reject Monsanto's Russet Burbank New Leaf GMO potato. Facing potential boycotts, McDonalds refused to purchase the potato and Monsanto withdrew it from the market in 1999 [15].

Values-based companies, whose brands are built on a reputation of social and environmental responsibility, are taking the lead in eliminating GMO ingredients and products from their stores entirely. For example, while the ice-cream maker, Ben \& Jerry's, does not consider GMOs unsafe they have responded to the anti-GMO backlash, moving to eliminate GMO ingredients from their products in an effort to reinforce their position as a socially and environmentally progressive firm with a commitment to "corporate transparency" [16,76]. As of August 2014, Ben \& Jerry's had 15 varieties of non-GMO ice cream and their goal is to have all their varieties made without GMO ingredients by the end of 2014 [76]. Chipotle is the first and only major food restaurant in the US to voluntarily label foods made with GMOs (as opposed to labeling non-GMO products) [77]. With its "Food With Integrity" philosophy, Chipotle also began its transition to eliminate GMOs from its ingredients early in 2014, for example, substituting sunflower oil for soybean oil [77]. Whole Foods Market, already the largest retailer for non-GMO products in North America with its 365 Everyday Value brand, announced in 2013 that it will require labeling of all products sold in its stores by 2018 [78]. Boulder Brands, which seeks to promote products that are perceived as enhancing health and wellness, reformulated its Smart Balance buttery spread and labeled it non-GMO in 2014. In taking these steps, these companies are reiterating the arguments of the 
GMO labeling movement, arguing that their consumers have a right to know what is in their food and that they are committed to providing greater transparency. For example, Chief executive of Boulder Brands Stephen Hughes explained, "Consumers are communicating a strong desire for more transparency in their food ingredients, and that is leading to a growing demand for non-GMO products" [65].

Most non-GMO labeling efforts or bans have occurred among companies with direct links to consumers, such as retailers, or among value-based brands, such as Boulder Brands. The significance of non-GMO political consumerism on mainstream food processors is less clear. On the one hand, the decision by retailers, such as Whole Foods, to ban GMOs will affect their suppliers. For example, the company thinkThin, whose largest buyer is Whole Foods, is working to remove GMOs from their Crunch snack bars [47]. On the other hand, the market necessity, willingness, or ability of major food manufacturers, such as Kraft or General Mills, to remove GMOs from their products appears limited.

To illustrate, in 2014, General Mills - a major contributor to the campaigns against mandatory labeling - surprised many when it introduced its non-GMO original Cheerios. Industry opponents of labeling argued that the company's decision lent credibility to misperceptions about the technology [16]. For its part, General Mills explained that it had made the decision "In the spirit of transparency" and had enrolled several products, including their organic products, in the Non-GMO Project Verified Project [79]. Since Cheerios are made primarily from oats (there are no GMO oats), the company only had to find alternatives to its GMO cornstarch and sugar, making the shift relatively easy. Despite the move the company continues to emphasize that they "oppose state-based labeling" [79], that GMOs are completely safe, and that the widespread use of GMO seeds in soybeans, corn, and sugar beets would make moving entirely to non-GMO ingredients a difficult, if not impossible task [80]. Furthermore, General Mills CEO Ken Powell explained that non-GMO labeling has not "affected competitive performance" therefore the cereal giant is not planning to introduce any more non-GMO products [81].

\section{Setting the Standard for Non-GMO Labels}

As mentioned above, there is no federal standard for non-GMO labels and this void is shaping up as an important site of political contestation over labeling. The widespread use of GMO crops means that even when ingredients are non-GMO sourced there is still a possibility for trace amounts of genetically engineered DNA to be present. A federal standard would establish a threshold for acceptable traces of genetically engineered DNA. As non-GMO marketing claims proliferate, the absence of a federal standard has raised concerns about the accuracy of company claims and the lack of transparency, which could affect consumer confidence as well as present liability issues for companies.

In the absence of a federal standard, the Non-GMO Project established its own standards and verification process for its non-GMO label. The Project requires on-going testing of any at-risk ingredients as well as requiring companies to adhere to "traceability and segregation practices" to ensure that the product remains non-GMO throughout [82]. To date, the Project has certified nearly 18,000 products from more than 1200 brands. The Project cannot legally claim its products to be "GMO free" because the contamination risks to seeds, crops, and ingredients are too high. The Non-GMO Project has established a tolerance level of $0.9 \%$ for acceptable traces of genetically modified DNA [82], which allows for some unintentional contamination. This is the same threshold set by the EU [83]. 
Demand for a federal standard for non-GMO labels is being driven by the agri-food industry as a clear alternative to mandatory labeling. Pompeo's Safe and Accurate Food Labeling Act (HR 4432) includes a proposal that the FDA would determine the permissible level of GMO presence in foods labeled non-GMO. The idea is widely supported by the GMA and most major food companies, retailers, farm and biotech groups, who are advocating for a standard that would be similar to the USDA Organic standard. For example, General Mills argues that it "supports a national standard for labeling of non-GMO products and that the USDA's standard and certification for organic products 'is an excellent model" " [79]. The USDA Organic standard has not set a tolerance level for GMOs and does not conduct testing making the standard less rigorous than that of the Non-GMO Project. Certified organic operators will face penalties, including the loss of certification, for intentional use of GMOs. However, if trace amounts of GMOs are found due to inadvertent presence then the operator is not in violation of USDA organic regulations [84].

Calls for a national standard for voluntary labels have propelled debate among anti-GMO groups who are divided over whether such a standard is needed. For example, Trudy Bialic, director of public affairs at PCC Markets, the largest natural food co-op in the US, rejects the idea arguing "We already have a national standard for labeling non-GMO foods ... the Non-GMO Project" [85]. In contrast, Carl Jorgensen, director of global consumer strategy-wellness at Daymon Worldwide, which overseas Kroger's Simple Truth brand, argues that "The trend for more transparency cannot be stopped, and a national standard would be the next step in non-GMO communication to consumers ... the same thing was seen when the earlier patchwork of organic standards was replaced by a national standard. Consumer confidence in organic increased" [85].

\section{Conclusions}

The recent expansion of private governance initiatives for GMO foods is one of the most significant developments in the two-decade-old battle against GMOs. This shift is not simply the result of abstract market forces or consumer demand but rather political processes. As Boström and Klintman (2008) note, labeling always takes place within "an organizational context" that "includes social movement mobilization and coalition building for or against labelling" [17] (p. 13). In this case, intransience at the federal level to ban or label GMOs prompted the anti-GMO movement to engage at the sub-political level. The grassroots was mobilized to campaign for mandatory labels within individual states while also targeting key food industry actors to ban or label GMO products. With the agri-food industry overwhelmingly opposed to mandatory labeling, tens of millions of dollars have poured into these high-stakes, state-level battles, successfully defeating each ballot proposal for labeling.

Yet, it appears that while these initiatives for mandatory labels failed at the ballot box they have energized the anti-GMO movement, garnered significant media attention, fuelled a national debate, and raised public awareness about GMOs. After the Oregon ballot measure, George Kimbrell, attorney for the Center for Food Safety, put it this way: "Every single person in Colorado and Oregon knows what a GMO is now" [52]. Growing public awareness of GMOs has translated into the fact that non-GMO labels are one of the fastest growing consumer trends within the food sector. Key food industry actors are eager to respond to this trend and help drive it through the development of non-GMO institutions, such as labels and branding. In responding to calls for enhanced transparency and choice regarding 
non-GMO products, food retailers and values-based food companies recognize the potential of non-GMO institutions to develop valuable niche markets aimed at political consumers. Non-GMO institutions also provide the opportunity for food companies to build trust, value, and status for their brand names, while potentially undermining calls for mandatory government labels for GMOs.

Ironically, for the anti-GMO movement the non-GMO governance efforts of food retailers and others may turn out to undermine the broader, long-term objectives of their cause. The GMO labeling movement emerged out of an anti-GMO movement that is fundamentally opposed to GMO crops and foods and ultimately seeks to banish them entirely from the agri-food system. This stance is rooted in broad based concerns that the technology is inherently tied to - and reinforces - an agri-food system that favors large-scale, corporate-controlled industrial production with little concern for socially and environmentally healthy and just outcomes for farmers, consumers, and the environment. From this perspective, GMOs are problematic because they perpetuate a system that relies on silver bullet technological fixes to address complex social and environmental problems, instead of approaches that emphasize holistic and systems thinking [86].

For the anti-GMO movement, non-GMO labels are viewed as a proxy for concerns about the sustainability of the agri-food system. However, non-GMO labels may ultimately function as a poor proxy. In their efforts to mobilize political consumer support for labeling, many of the movement's sustainability concerns are brushed aside in favor of a discourse that emphasizes individualist concerns about choice, right to know and transparency. These arguments appeal to a minority of political consumers who embrace labels as a means of enhancing transparency and reducing information asymmetries so that their consumption practices can reflect their social and ethical values. As a result, niche markets for non-GMO products will expand, offering an important market opportunity for a small segment of producers to meet this demand. However, if political consumers feel that they can fulfill their social and ethical values by making good choices in the marketplace for themselves and their families then there is little incentive for them to act on broader structural changes that could lead to an agri-food system that is more socially and environmentally just for everyone.

In sum, voluntary labels may act to settle the GMO labeling debate by meeting the desire of political consumers for greater choice and transparency, providing a profitable niche market for retailers, while also allaying agri-food industry concerns about mandatory labeling. Yet, voluntary labels are unlikely to fundamentally address the social and environmental sustainability concerns of the anti-GMO movement with GMO crops likely to continue to expand as a mainstay of the US agri-food system and the "fix" for much of what ails it.

\section{Acknowledgments}

This research was supported by the USDA-National Institute of Food and Agriculture (NIFA) under Grant No. 2013-68004-20374. Any opinions, findings, and conclusions expressed in this material are those of the authors and do not necessarily reflect the views of the USDA. The authors would like to express their appreciation to all those who kindly agreed to participate in this research project. The authors would also like to thank the anonymous reviewers for their valuable comments on an earlier version of this article. 


\section{Author Contributions}

Carmen Bain conceptualized the project, designed the research methodology and conducted the literature review. Both Carmen Bain and Tamera Dandachi conducted the interviews, analyzed the data, and wrote the paper. Both authors have read and approved the final manuscript.

\section{Conflicts of Interest}

The authors declare no conflict of interest.

\section{References and Notes}

1. The term GMO (genetically modified organism) has become the common signification for genetically engineered (GE) foods. Although the terms are not technically the same, they will be used interchangeably in this paper to express the growing movement against corporate agriculture and the use of genetic engineering within agriculture.

2. Tracy, T. GMO labeling faces ballot test in Oregon, Colorado. Available online: http://online.wsj.com/articles/gmo-labeling-faces-ballot-test-in-oregon-colorado-1414961328 (accessed on 10 November 2014).

3. In addition, there was a ballot initiative in Oregon in 2002 (Measure 27) to mandate GM labels, which was defeated. In 2005, Alaska had passed a law that would mandate labeling of GM fish sold in the state. However, GM fish have yet to be approved by the FDA.

4. Kaste, M. So what happens if the movement to label GMOs succeeds. NPR: 2013. Available online: http://www.npr.org/blogs/thesalt/2013/10/16/235525984/so-what-happens-if-the-movement-tolabel-gmos-succeeds (accessed on 10 November 2014).

5. National Academy of Sciences. Webcast archive: First meeting. Available online: http://nas-sites.org/ ge-crops/2014/09/24/webcast-archive-first-meeting/ (accessed on 10 November 2014).

6. Price, J. National Academy of Sciences. Available online: http://gmoanswers.com/studies/ top-10-consumer-questions (accessed on 10 November 2014).

7. Schurman, R.; Munro, W. Fighting for the Future of Food; University of Minnesota Press: Minneapolis, MN, USA, 2010.

8. Wohlers, A.E. Regulating genetically modified food. Polit. Life Sci. 2010, 29, 17-39.

9. Caswell, J. Labeling policy for GMOs: To each his own? AgBioForum 2000, 3, 53-57.

10. Eenennaam, A.; Chassy, B.; Kalaitzandonakes, N.; Redick, T. The potential impacts of mandatory labeling for genetically engineered food in the United States. Available online: http://www.castscience.org/file.cfm/media/products/digitalproducts/CAST_Issue_Paper_54_web_ optimized_29B2AB16AD687.pdf (accessed on 4 December 2014).

11. Klintman, M. Arguments surrounding organic and genetically modified food labelling: A few comparisons. J. Environ. Policy Plan. 2002, 4, 247-259.

12. Sand, P.H. Labelling genetically modified food: The right to know. Rev. Eur. Community Int. Environ. Law 2006, 15, 185-192.

13. Wohlers, A.E. Labeling of genetically modified food. Polit. Life Sci. 2013, 32, 73-84. 
14. Center for Science in the Public Interest (CPI). Straight Talk on Genetically Engineered Foods; CPI: Washington, DC, USA, 2012.

15. Fernandez-Cornejo, J.; Wechsler, S.J.; Livingston, M.; Mitchell, L. Genetically Engineered Crops in the United States. Available online: http://www.ers.usda.gov/publications/err-economicresearch-report/err162.aspx (accessed on 4 December 2014).

16. Gasparro, A. The GMO fight ripples down the food chain. Available online: http://online.wsj.com/ articles/the-gmo-fight-ripples-down-the-food-chain-1407465378 (accessed on 10 November 2014).

17. Boström, M.; Klintman, M. Eco-Standards, Product Labelling and Green Consumerism; Palgrave Macmillan: Hampshire, UK, 2008.

18. Roff, R. Shopping for change? Neoliberalizing activism and the limits to eating non-GMO. Agric. Hum. Values 2007, 24, 511-522.

19. Busch, L. The private governance of food: Equitable exchange or bizarre bazaar? Agric. Hum. Values 2011, 28, 345-352.

20. Raynolds, L.T.; Long, M.A.; Murray, D.L. Regulating corporate responsibility in the American market: A comparative analysis of voluntary certifications. Compet. Chang. 2014, 18, 91-110.

21. Bain, C.; Ransom, E.; Higgins, V. Private agri-food standards: Contestation, hybridity and the politics of standards. Int. J. Food Agric. 2013, 20, 1-10.

22. Fuchs, D.; Kalfagianni, A. Private Food Governance and Implications for Social Sustainability and Democratic Legitimacy. In Corporate Social Responsibility and Regulatory Governance; Utting, P., Marques, J.C., Eds.; Palgrave Macmillan: Hampshire, UK, 2010; pp. 225-247.

23. Henson, S. Private agrifood governance: Conclusions, observations and provocations. Agric. Hum. Values 2011, 28, 443-451.

24. Consumers Union. Mission. Available online: https://consumersunion.org/about $/ \mathrm{mission} /$ (accessed on 10 November 2014).

25. Institute for Agriculture and Trade Policy. About IATP. Available online: http:/www.iatp.org/ about (accessed on 10 November 2014).

26. Organic Consumers Union. Millions against Monsanto. Available online: http://www.organicconsumers.org/monsanto/ (accessed on 10 November 2014).

27. DeLind, L.B. Are local food and the local food movement taking us where we want to go? Or are we hitching our wagons to the wrong stars? Agric. Hum. Values 2011, 28, 273-283.

28. Hatanaka, M.; Bain, C.; Busch, L. Third-party certification in the global agrifood system. Food Policy 2005, 30, 354-369.

29. Flora, C.; Bain, C.; Call, C. Sustainability standards and their implications for agroecology. In Integrating Agriculture, Conservation, and Ecotourism: Societal Influences; Campbell, B., Lopez Ortiz, S., Eds.; Springer: Berlin/Heidelberg, Germany, 2012; pp. 163-225.

30. Bartley, T.; Child, C. Shaming the corporation the social production of targets and the anti-sweatshop movement. Am. Sociol. Rev. 2014, 79, 653-679.

31. Busch, L.; Bain, C. New! Improved? The transformation of the global agrifood system. Rural Sociol. 2004, 69, 321-346.

32. Giovannucci, D.; Ponte, S. Standards as a new form of social contract? Sustainability initiatives in the coffee industry. Food Policy 2005, 30, 284-301. 
33. Henson, S.; Reardon, T. Private agri-food standards: Implications for food policy and the agri-food system. Food Policy 2005, 30, 241-253.

34. Chkanikova, O.; Lehner, M. Private eco-brands and green market development: Towards new forms of sustainability governance in food retailing. J. Clean. Prod. 2014, doi:10.1016/j.jclepro.2014.05.055.

35. Allaire, G. Applying economic sociology to understand the meaning of "quality" in food markets. Agric. Econ. 2010, 41, 167-180.

36. Loureiro, M.L.; Hine, S. Discovering niche markets: A comparison of consumer willingness to pay for local (Colorado grown), organic, and GMO-free products. J. Agric. Appl. Econ. 2002, 34, 477-488.

37. Tully, S.; Winer, R. Are people willing to pay more for socially responsible products: A meta-analysis. Available online: http://ssrn.com/abstract=2240535 (accessed on 4 December 2014).

38. Loureiro, M.L.; Lotade, J. Do fair trade and eco-labels in coffee wake up the consumer conscience? Ecol. Econ. 2005, 53, 129-138.

39. Barrientos, S.; Dolan, C. Ethical Sourcing in the Global Food System; Earthscan: London, UK, 2006.

40. Klintman, M.; Boström, M. Political consumerism and the transition towards a more sustainable food regime. Looking behind and beyond the organic shelf. In Food Practices in Transition: Changing Food Consumption, Retail and Production in the Age of Reflexive Modernity; Spaargaren, G., Loeber, A., Oosterveer, P., Eds.; Routledge: New York, NY, USA, 2011; pp. 107-130.

41. Mol, A.P.J. Transparency and value chain sustainability. J. Clean. Prod. 2013, doi:10.1016/j.jclepro.2013.11.012.

42. Levidow, L.; Murphy, J.; Carr, S. Recasting “substantial equivalence": Transatlantic governance of gm food. Sci. Technol. Hum. Values 2007, 32, 26-64.

43. Jasanoff, S. Between risk and precaution-reassessing the future of GM crops. J. Risk Res. 2000, 3, 277-282.

44. Food and Drug Administration. Genetically Engineered Foods. Available online: http://www.fda.gov/ newsevents/testimony/ucm115032.htm (accessed on 10 November 2014).

45. Harmon, A.; Pollack, A. Battle brewing over labeling of genetically modified food. Available online: http://www.nytimes.com/2012/05/25/science/dispute-over-labeling-of-geneticallymodified-food.html?_r=0 (accessed on 10 November 2014).

46. Sjerven, J. U.S.D.A. approves 'non-bioengineered' label. Available online: http://www.nxtbook.com/ sosland/fbn/2013_07_02/index.php?startid=44 (accessed on 4 December 2014).

47. Strom, S. US approves a label for meat from animals fed a diet free of gene-modified products. Available online: http://www.nytimes.com/2013/06/21/business/us-approves-a-label-for-meatfrom-animals-fed-a-diet-free-of-gene-modified-products.html?_r=0 (accessed on 10 November 2014).

48. D'Ambrosio, D. Labels sought for genetically modified food. Available online: http://www.usatoday.com/story/money/business/2013/06/12/labels-being-sought-for-geneticallymodified-food/2417459/ (accessed on 10 November 2014).

49. Grobe, D.; Raab, C. Voters' response to labeling genetically engineered foods: Oregon's experience. J. Consum. Aff. 2004, 38, 320-331.

50. Hoban, T.J. American consumers' awareness and acceptance of biotechnology. In NABC Report 13: Genetically Modified Food and the Consumer; Eaglesham, A., Pueppke, S.G., Hardy, R.W.F., Eds.; 2001; pp. 51-68. 
51. Tims, D. Dr. Bronner's betting big on Oregon's pro-GMO labeling campaign. Available online: http://www.oregonlive.com/politics/index.ssf/2014/09/dr_bronners_betting_big_on_ore.html (accessed on 10 November 2014).

52. Gasparro, A.; Bunge, J. Food industry wins round in GMO-labeling fight. Available online: http://online.wsj.com/articles/colorado-voters-defeat-proposal-to-require-gmo-labeling-of-foods1415206857 (accessed on 10 November 2014).

53. \#102, Consumers organization. Personal communication, 2013.

54. Boyd, V. Vermont appears on verge of passing GMO labeling law. Available online: http://www.thegrower.com/news/Vermont-appears-on-verge-of-passing-GMO-labeling-law256555221.html (accessed on 10 November 2014).

55. \#111, Environmental organization. Personal communication, 2014.

56. CSPI is not in favor of GMO labeling advocating instead that consumers purchase certified USDA organic if they wish to avoid GMOs.

57. Oregon Right to Know. Why label GMO foods. Available online: http://oregonrighttoknow.org/ why-label-gmos-or-ge-food/ (accessed on 10 November 2014).

58. \#116, Agriculture policy organization. Personal communication, 2014.

59. \#107, Biotech company. Personal communication, 2013.

60. Remsen, N. Trade groups sue VT over GMO labeling law. Available online: http:/www.burlingtonfreepress.com/story/news/politics/2014/06/12/gma-sues-vt-gmo-law/10389209/ (accessed on 10 November 2014).

61. \#104, Government biotechnology official. Personal communication, 2013.

62. Loureiro, M.L.; Hine, S. Preferences and willingness to pay for GM labeling policies. Food Policy 2004, 5, 467-483.

63. This number is based on a 2014 study conducted by Lesser and Lynch that addresses the costs of producing GM food in the state of New York. The study presents cost estimates for three different options that firms would have in complying with a mandatory labeling law: Labeling, substituting non-GMO ingredients, or substituting organic. The study presents various cost ranges based on aggregates of these with higher costs being associated with purchasing a higher percentage of organic products.

64. ECONorthwest. GE foods labeling cost study findings. Available online: https://consumersunion.org/ wp-content/uploads/2014/09/GMO_labeling_cost_findings_Exe_Summ.pdf (accessed on 10 November 2014).

65. MacVean, M. Company says no more GMO ingredients in Smart Balance spreads. Available online: http://articles.latimes.com/2014/mar/04/news/la-dd-smart-balance-20140304 (accessed on 10 November 2014).

66. Hughlett, M. Target rolling out organic, natural grocery brand. Available online: http://www.startribune.com/business/210659481.html (accessed on 10 November 2014).

67. Hale, T. How 10 retailers are pushing private label's potential. Available online: http://www.nielsen.com/content/corporate/us/en/insights/news/2014/how-10-retailers-arepushing-private-labels-potential.html (accessed on 10 November 2014).

68. Peckenpaugh, D. Top 35 private label retailers. Available online: http://www.privatelabelbuyer.com/ articles/87669-top-35-private-label-retailers (accessed on 10 November 2014). 
69. Davis, S. How Target, Walgreens and Home Depot have forever changed the private label game. Available online: http://www.forbes.com/sites/scottdavis/2013/05/23/how-target-walgreens-andhome-depot-have-forever-changed-the-private-label-game/ (accessed on 10 November 2014).

70. Peckenpaugh, D. PLbuyer names Whole Foods 2014 retailer of the year. Available online: http://www.privatelabelbuyer.com/articles/87767-plbuyer-names-whole-foods-2014-retailer-ofthe-year (accessed on 10 November 2014).

71. Trader Joe's. Trader Joe's products are sourced from non-GMO ingredients. Available online: http://www.traderjoes.com/about/customer-updates-responses.asp? $\mathrm{i}=4>$ (accessed on 10 November 2014).

72. Greenfeld, K. GMO-free private label leads the pack. Available online: http://supermarketnews.com/ blog/gmo-free-private-label-leads-pack (accessed on 10 November 2014).

73. Schultz, H. GMO labeling push will propel organic market, Organic Monitor says. Available online: http://www.foodnavigator-usa.com/Markets/GMO-labeling-push-will-propel-organic-marketOrganic-Monitor-says (accessed on 10 November 2014).

74. Gillespie, J.; Nehring, R.; Hallahan, C.; Sandretto, R. Adoption of recombinant bovine somatotropin and farm profitability: Does farm size matter? AgBioForum 2010, 13, 251-262.

75. Wong, V. Grocers line up — early_against biotech salmon. What about Wal-Mart? Available online: http://notinmyfood.org/article/grocers-line-up-early-against-biotech-salmon-what-about-wal-mart (accessed on 4 December 2014).

76. Ben \& Jerry's. Our non-GMO standards. 2014. Available online: http://www.benjerry.com/ values/issues-we-care-about/support-gmo-labeling/our-non-gmo-standards (accessed on 10 November 2014).

77. Hughes, C. Chipotle GMO labels: Setting precedent for fast food industry? Available online: http://www.newsmax.com/TheWire/chipotle-gmo-labels-fast-food/2013/06/18/id/510489/ (accessed on 10 November 2014).

78. Whole Foods Market. GMO: Your right to know. Available online: http://www.wholefoodsmarket.com/gmo-your-right-know (accessed on 5 August 2014).

79. General Mills. National labeling — not state-by-state. Available online: http://www.generalmills.com/ en/ChannelG/Issues/national_labeling_2014.aspx (accessed on 4 December 2014).

80. Horovitz, B. Cheerios drops genetically modified ingredients. Available online: http://www.usatoday.com/story/money/business/2014/01/02/cheerios-gmos-cereals/4295739/ (accessed on 10 November 2014).

81. Buss, D. Americans still aren't buying GMO-free gospel. Just ask General Mills. Available online: http://www.forbes.com/sites/dalebuss/2014/02/20/americans-still-arent-buying-gmo-gospel-askgeneral-mills/ (accessed on 10 November 2014).

82. Non-GMO Project. The "Non-GMO Project Verified" seal. Available online: www.nongmoproject.org/learn-more/understanding-our-seal/ (accessed on 10 November 2014).

83. Davison, J. GM plants: Science, politics and economic regulations. Plant Sci. 2014, 178, 94-98.

84. McEvoy, M. Organic 101: Can GMOs be used in organic products? Available online: http://blogs.usda.gov/2013/05/17/organic-101-can-gmos-be-used-in-organic-products/ (accessed on 4 December 2014). 
85. Roseboro, K. Experts say GMO labels needed, not national non-GMO labeling standard. Available online: http:/www.non-gmoreport.com/articles/september-2014/experts-say-gmo-labels-needednot-non-gmo-labeling.php (accessed on 4 December 2014).

86. Foley, J. GMOs, silver bullets and the trap of reductionist thinking. Available online: http://ensia.com/voices/gmos-silver-bullets-and-the-trap-of-reductionist-thinking/ (accessed on 4 December 2014).

(C) 2014 by the authors; licensee MDPI, Basel, Switzerland. This article is an open access article distributed under the terms and conditions of the Creative Commons Attribution license (http://creativecommons.org/licenses/by/4.0/). 